\title{
EFFECTUALITY OF COMIC STRIP AS INSTRUCTIONAL MATERIAL TO THE ACADEMIC ACHIEVEMENT OF STUDENTS IN SCIENCE 8 CONCEPTS
}

\author{
Melinda E. Calejesan, John Manuel C. Buniel \\ Carrascal National High School; melinda_calejesan@gmail.com \\ Surigao del Sur State University-Cantilan Campus; johncotaresbuniel@gmail.com
}

\begin{abstract}
The study was carried out to evaluate the effectuality of developed comic strips as an instructional material for teaching specific concepts in science 8; the digestive system. In particular, the aim of the study is to analyze the effects of the evaluation ratings of the comic strips produced and the effect of its implementation. It also assessed the view of respondents on the use of developed comic strips to strengthen their skills in the science process. It also examines the significant difference between the respondents' academic performances when supported by created comic strips. The primary instrument of the study was the existing comic strip rubrics and survey questionnaire. These instruments have been tested by different experts. The results show that the validated comic strip is identified by the experts as appropriate and commendable. The achievement of the respondents has improved substantially. The participants strongly agree on the usefulness of developed comic strips in the teaching of digestive system concept. There is a substantial gap between the respondents' academic success using established comic strips and conventional approaches. In teaching the digestive system, the developed comic strip is appropriate to use as a material and greatly enhanced the respondents' efficiency.
\end{abstract}

KEYWORDS: Comic Strips; Instructional Materials; Digestive System; Academic Performance

\section{INTRODUCTION}

The teaching effectiveness of the teacher and the learning of the student is often based on the instructional materials (IMs) used. Muzumdar (2016) noted that there are numerous studies supporting the claim that IMs influence the learning of students. Traditional teaching approaches, according to Özdemir (2010), have a negative impact on the teaching process, particularly in the development of the scientific process skills of students. As an educational tool, Comic Strips had proven its usefulness in literacy and related language art fields, where many claims had made it a productive instrument for providing enjoyment, good motivational activity, learning atmosphere and improving understanding in a nonthreatening manner, thus making the material important to the field of education.

The study is based on the ideas of Gary (2012), Espada (2003) and Özdemir (2010) that comics can promote the learning of overarching concepts by students, such as cognitive growth, motivation and information processing, as an educational content. The scientifically sound comic strip is also an innovative way of fostering higher-order thinking skills by putting scientific knowledge into a popular format that most students enjoy. The study sought to fill the gaps between existing postulates by promoting another concept on comic strips as a positive tool to enhance the progress of students in a specific science concept and how it enhances their skills in the science process. 


\section{METHODOLOGY}

The study used the "design and development" method of research adapted from the study conducted by the Institute of Education Science [IES] (2013) and Özdemir (2016) to construct an instructional material based on an existing theory and to gain input on the progress of students in a particular scientific concept and the development of their process skills. For two main stages, the design was deemed appropriate: the first phase was creative writing scenario duties and the drawing of comic strips with expert input. The second stage was to create and review the comic strips that were created, concentrating on the notion of digestive system. In terms of its content, format, presentation and organization and accuracy and up-to-datedness of information, the formed comic strip was assessed. The assessment phase was followed by the implementation of a pilot analysis of the responses of the participants. At this point, through content analysis, the researchers' investigated the responses and reactions of participants to the implementation of established comic strips.

\section{RESULT}

Table 1. Summary Table of the Evaluation Rating of Comic Strips

\begin{tabular}{|l|c|c|}
\hline Area of Assessment & WM & Descrintion \\
\hline Factor 1: Content & 4.00 & Very Satisfactory \\
\hline Factor 2: Format & 4.00 & Very Satisfactory \\
\hline Factor 3: Presentation and Organization & 3.92 & Very Satisfactory \\
\hline Factor 4: Accuracy and Up-to-datedness of Information & 4.00 & Very Satisfactory \\
\hline Overall Mean & $\mathbf{3 . 9 8}$ & Very Satisfactory \\
\hline
\end{tabular}

Legend: 4.00-3.1- Very Satisfactory (VS), 3.00-2.1- Satisfactory (S), 2.00-1.1- Fair, 1.00-Poor

Table 2. Mean Scores and Standard Deviation value of the Pretest and Posttest

\begin{tabular}{|c|c|c|c|c|c|c|c|}
\hline \multicolumn{4}{|c|}{ Traditional } & \multicolumn{4}{c|}{ Using Comic Strips } \\
\hline \multicolumn{2}{|c|}{ Pre-test } & \multicolumn{2}{c|}{ Post-test } & \multicolumn{2}{c|}{ Pre -test } & \multicolumn{2}{c|}{ Post test } \\
\hline Mean & SD & Mean & SD & Mean & SD & Mean & SD \\
\hline $\mathbf{7 . 3}$ & $\mathbf{2 . 4 6}$ & $\mathbf{9 . 0 3}$ & $\mathbf{2 . 9 5}$ & $\mathbf{8 . 4 7}$ & $\mathbf{1 . 9 1}$ & $\mathbf{1 2 . 9 2}$ & $\mathbf{2 . 6 8}$ \\
\hline
\end{tabular}

Table 3. Summary Table of the Weighted Mean Distribution of the Level of Perceptions of the Respondents on the Use of Developed Comic Strips in Teaching Digestive System

\begin{tabular}{|l|c|c|}
\hline Comic Strins Heln Learning (LEA) & Weighted Mean & Description \\
\hline A. Retention (RET) & 3.77 & Strongly Agree \\
\hline B. Comprehension (COM) & 3.83 & Strongly Agree \\
\hline C. Science Process Skills (SPS) & 3.82 & Strongly Agree \\
\hline Overall Mean & 3.80 & Strongly Agree \\
\hline
\end{tabular}

Legend: 4.00-3.1- Strongly Agree, 3.00-2.1- Agree, 2.00-1.1- Disagree, 1.00-Strongly Disagree

Table 4. T-test for Equality Means

\begin{tabular}{|c|c|c|c|c|}
\hline Academic Performance & F-value & p-value & Decision & Conclusion \\
\hline Control Group & .40 & .000 & Reject Null & Significant \\
\hline
\end{tabular}


\begin{tabular}{|l|l|l|l} 
Experimental Group & & & Hypothesis \\
\hline
\end{tabular}

\section{DISCUSSION}

In terms of content, format, presentation and organization and accuracy and up-to-datedness, the created comic strip was evaluated by various experts. The findings indicate that a verbal explanation of the comic strip was viewed as appropriate and commendable with a verbal description of Very satisfactory. The researchers determined that there is a high level of acceptability for comic strips. The experts therefore considered the material as potential instructional materials that can improve the performance of learners in a specific concept. The experimental group showed improved results in the science concepts presented using comics during the conduct of the study. Ozdemir's (2010) supported the claim that comics are involved in promoting productive classrooms and students' willingness to read to learn. The improvement in their mean score shown in Table 2 indicates that the students have a better understanding of the concepts of the digestive system and have conducted the activities given to them well. The study conducted by Mallia (2007) validated the finding that comic as a teacher-independent content demonstrates the instrument's vital capacity as a cognitive and efficient instrument for the purposes of motivation and retention of the pupil.

The assessment of the perception of the students towards the use of comic strip in teaching the digestive system showed a positive reaction. Results showed that student respondents typically have favorable attitudes towards comic strips as teaching tools, science process skills, for learning science concepts. They seemed to have understood more, improved their abilities in the scientific method and showed the visionary trend. In his report, Enteria \& Casumpang (2019) in their study, they concluded that comic strips are highly accepted and recommended in classrooms for use. In addition, Daniels (2019) stated that visuals could satisfy the need for information processing and learning for learners. For learners, comics are inherently imaginative and enjoyable. Compared to no illustrated text, the visual aspect of comics will certainly provide pathways for student success. In addition, the result demonstrates that there is a substantial difference between the participants' academic success in the definition of teaching science through the use of the established comic strip and the conventional teaching process. The assumption is also embedded in the study by Arroio (2011) and Weber, et al. (2013), which notes that the use of visual and text style presentations allows comics the opportunity to use conventional textbook materials to get away from traditional classroom delivery.

\section{CONCLUSION}

The researchers concluded on the basis of the results of the study that the comic strip is widely accepted and commendable for use in the classroom environment. Activities pertaining to comic strips performed better than those who did not undergo the conventional approach or treatment. In addition, students perceived that comic strip helped promote good understanding, increased the development of their skills in the science process and raised greater knowledge of digestive system topics. Future researchers in other fields are encouraged to create another package of comic strips. It is also advised to 
use this comic strip as an educational material for teaching specific science concepts and a platform to raise awareness and advocate for health.

\section{REFERENCES}

Acar B, Tarhan L (2008) Teaching Grade 5 Life Science With a Case Study Approach. Research in Science Education. 38(4): 401-420.

Arroi, A. (2011). Comics s an Alternative in Natural Science Education: Western Anatolia Journal of Educational Sciences(WAJES). Turkey.

Enteria, O. and Casumpang, P. (2018). Effectiveness of developed comic strips as instructional material in teaching specific science concepts.

Cocal C. and Gertrudes,M.(2017)Challenges of K-12 Program Implementation in Public Elementary of Pangasinan,Phil.

Daniels ,S.(2017) Visual Learning and Teaching

Dela Cruz, M. (n.d.). Effects of lack of instructional material. Retrieved from:. http://www Academia.eu /13158439 /effects-of-lack-onin structional-materials, September 21, 2018.

Dy, L. (2011). Teaching Physics through Strategic Intervention Materials. http://jhody.hubpages.com. Date Retrieved: March 06, 2015.

Durban, J. M., \& Catalan, R. D. (2012). Issues and concerns of Philippine education through the years. Asian Journal of Social Sciences \& Humanities, 1(2), Retrieved fro http ://www ajssh.leenaluna.co.jp / AJSSHPDFs/Vol .1(2)/ AJSSH201 2(1.2-08).pdf

Espada, W. (2003). Integrating physical science and the graphic arts with scientifically accurate comic strips: rationale, description, and implementation: Revista Electrónica de Enseñanza de las Ciencias, Vol. 2, $\mathrm{N}^{\circ}$ 1, 58-66 (2003), USA.

Law of Phil.Education Act.

Krusemark,R.(2015)Comic books in the American College Classroom;A Study of critical Thinking.

Macarandang, M. A. Evaluation of a Proposed Set of Modules in Principles and Methods of Teaching. EInternational Scientific Research Journal, 1,. 2009

Mwadisi(2016)The influence of teaching and learning Materials on Students Performance in Secondary School

Muzumdar, J. (2016). An Overview of Comic Books as an Educational Tool and Impli- cations forPharmacy, Innovation in Pharmacy: University of Minnesota Libraries, Vol.7 (4): Article 1. 
National Center for Education Statistics (2007). Trends in international mathematics andscience study. Washington, DC: retrieved from: http://nces.ed.gov/timss/results07_science07.asp.

Ogier,Gosh(2017).Exploring Student teachers capacity for creativity through interdisciplinary use of comics in the primary classroom.

Olson(2018)E-comics in teaching.Evaluating and using comic strip as creators tool

Ozdemir, E. (2017). Humor in Elementary Science: Development and Evaluation of Comic Strips about Sound: International electronic Journal of elementary education, June 2017,9(4), 837-850,Turkey

Rionda(2006)Production and Development of locally produced teaching materials.

Paunesko et al(2015)-Mind-Set Interventions are Scalable Treat for Academic Underachievement.

Software of Educators(2016)-E comics in teaching Evaluating and using comic strip creator tool for educational purposes.

Souza, C. S., Iglesias, A. G., \& Pazin-Filho, A. (2014). Estratégias inovadoras para métodos de ensino tradicionais - aspectos gerais. Medicina, 43(3), 284-292

Sugirin,(2019).The Effectiveness of using Comic Strips to Increase reading. 